Blagica Cekova ${ }^{*}$, Filip Jovanovski², Viktorija Bezhovska²

${ }^{1}$ MIT University, Faculty of ecological resources menagment, Skopje, Republic of Macedonia, ${ }^{2}$ University of Skopje, Faculty of Technology and Metallurgy, Skopje, Republic of Macedonia
Scientific paper

ISSN 0351-9465, E-ISSN 2466-2585

UDC:620.192.2.195.549.67

doi: $10.5937 /$ ZasMat $1604519 \mathrm{C}$

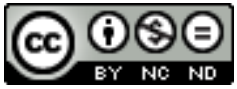

Zastita Materijala 57 (4)

$519-522(2016)$

\title{
Modification of $\mathrm{NaY}$ zeolite by citric acid through application of tensides
}

\begin{abstract}
The zeolites are popular group of minerals for collectors and important group of minerals for industrial and other purposes. They combine rarity, beauty, complexity and unique crystal habits. Typically forming in the cavities, or vesicles, of volcanic rocks, zeolites are the result of very low grade metamorphism. Some are formed from just subtle amounts of heat and pressure and can just barely be called metamorphic, while others are found in obviously metamorphic regimes. There is undergoing extensive research into the formation of zeolites and their unique properties.

The NaY zeolite is analogue to the natural zeolite phosphazide and belongs to the $I V^{\text {th }}$ group according to the zeolite classification. The typical composition of NaY elementary cell is $\mathrm{Na}_{56}\left[\left(\mathrm{AlO}_{2}\right)_{56}\left(\mathrm{SiO}_{2}\right)_{136}\right] \cdot 250 \mathrm{H}_{2} \mathrm{O}$ containing double hexagonal rings $\left(D_{6} R\right)$. This research was focused on a $\mathrm{NaY}$ zeolite, obtained by hydro-thermal procedure with a chosen oxide ratio: $\mathrm{SiO}_{2} / \mathrm{Al}_{2} \mathrm{O}_{3}=9.0$; $\mathrm{Na}_{2} \mathrm{O} / \mathrm{SiO}_{2}=0.33 ; \mathrm{H}_{2} \mathrm{O} / \mathrm{Na}_{2} \mathrm{O}=40$. The chemical composition of the starting mixture for the synthesis is determined by the chemical formula $2.97 \mathrm{Na}_{2} \mathrm{O} \cdot \mathrm{Al}_{2} \mathrm{O}_{3} \cdot 9 \mathrm{SiO}_{2} \cdot 118.8 \mathrm{H}_{2} \mathrm{O}$. The dealumination process on the $\mathrm{NaY}$ zeolite was performed by application of citric acid with concentrations of 0.1 and $0.5 \mathrm{~mol} / \mathrm{dm}^{3}$ and introduction of tensides (I, II, III, IV). Dealumination procedure is conducted in order to extract the most of the Al content from the zeolite structure while preserving the crystal structure, with crystalinity above $50 \%$. NaY zeolite has a solid structure and therefore a dealumination process is required in order to modify this material into a suitable catalyst, as well as for other uses. Obtained products were analyzed by X-Ray, and DTA, TGA and DTG. The results of the performed dealumination are presented in tables. Crystalinity was determined as $56.90 \%$, compared to the crystalinity of the commercial zeolite that has a reported crystalinity of $100 \%$.
\end{abstract}

Keywords: dealumination, citric acid, NaY zeolite, crystalinity.

\section{INTRODUCTION}

There are several types of synthetic zeolites that form by a process of slow crystallization of a silica-alumina gel in the presence of alkalis and organic templates. One of the important processes used to carry out zeolite synthesis is sol-gel processing. The product properties depend on reaction mixture composition, $\mathrm{pH}$ of the system, operating temperature, pre-reaction 'seeding' time, reaction time as well as the templates used. In solgel process, other elements (metals, metal oxides) can be easily incorporated. The silicalite sol formed by the hydrothermal method is very stable.

\footnotetext{
${ }^{*}$ Corresponding author: Blagica Cekova

E-mail: cekovab@yahoo.com

Paper received: 22. 01. 2016.

Paper accepted: 16. 03. 2016.

Paper is available on the website: www.idk.org.rs/journal
}

The ease of scaling up this process makes it a favorite route for zeolite synthesis [1,2]. The structure of NaY zeolite is given in Figure 1.

\section{EXPERIMENTAL PART AND DISCUSSION}

$\mathrm{NaY}$ zeolite obtained by hydro thermal procedure was used for the examinations. Citric acid that was used has concentrations $c=0,1$ $\mathrm{mol} \cdot \mathrm{dm}^{-3}$ and $\mathrm{c}=0,5 \mathrm{~mol} \cdot \mathrm{dm}^{-3}$. Surfactants I, II, III and IV were also used. Surfactants are organic compounds which can be cationic, anionic and neutral. For our examinations anionic surfactants were used. They are prepared with different concentrations and are used for Nay zeolite treatment with citric acid. The results show that surfactants have no effect on the extraction of aluminum from the zeolite structure. The results for aluminum content in the samples $\mathrm{NaY}$ zeolite + citric acid + surfactants and without surfactants, are listed in Table 1 and Table 2. Using the citric acid with concentration of $0,1 \mathrm{~mol} \cdot \mathrm{dm}^{-3}$ the crystallinity 
of the resulting modified NaY zeolite is $56,90 \%$, while the use of citric acid with $\mathrm{c}=0,5 \mathrm{~mol} \cdot \mathrm{dm}^{-3}$ provides amorphous product, destroyed crystal lattice. The diffractogram of NaY zeolite is given in Figure 2. Reflections occur at a certain angle range

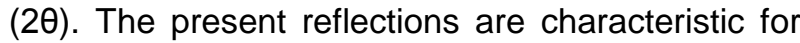
the structure of the NaY zeolite and its crystallinity is $100 \%$.

Table 1 - NaY zeolite + citric acid + surfactants and without surfactants

\begin{tabular}{|c|c|c|c|c|}
\hline Serie & Tenzides & $\begin{array}{l}\text { Concetration } \\
(\mathrm{ml} / \mathrm{l})\end{array}$ & $\begin{array}{l}\text { Time } \\
\text { (h) }\end{array}$ & $\begin{array}{c}\mathrm{Al} \\
(\% \text { mass })\end{array}$ \\
\hline $1^{\prime}$ & \multirow{3}{*}{1} & 0.5 & 2 & 29.09 \\
\hline $2^{\prime}$ & & 0.5 & 4 & 29.54 \\
\hline $3^{\prime}$ & & 0.5 & 6 & 29.09 \\
\hline $1 "$ & \multirow{3}{*}{ II } & 0.5 & 2 & 29.43 \\
\hline $2 "$ & & 0.5 & 4 & 28.96 \\
\hline $3 "$ & & 0.5 & 6 & 28.95 \\
\hline $1 " '$ & \multirow{3}{*}{ III } & 0.5 & 2 & 29.09 \\
\hline 2"' & & 0.5 & 4 & 29.09 \\
\hline 3"' & & 0.5 & 6 & 27.27 \\
\hline $1 " '$, & \multirow{3}{*}{ IV } & 0.5 & 2 & 28.82 \\
\hline 2"”' & & 0.5 & 4 & 29.11 \\
\hline 3"'” & & 0.5 & 6 & 29.32 \\
\hline 1"'”' & & 0.5 & 2 & 28.95 \\
\hline 2"'”' & & 0.5 & 4 & 29.09 \\
\hline 3"'”' & & 0.5 & 6 & 28.95 \\
\hline
\end{tabular}

Table 2 - NaY zeolite + citric acid + surfactants and without surfactants

\begin{tabular}{|c|c|c|c|c|}
\hline Serie & Tenzides & $\begin{array}{c}\text { Concetration } \\
\mathrm{ml} / \mathrm{dm}^{3}\end{array}$ & $\begin{array}{l}\text { Time } \\
\text { (h) }\end{array}$ & $\begin{array}{c}\mathrm{Al} \\
\text { (\%mas) }\end{array}$ \\
\hline $1^{\prime}$ & \multirow{3}{*}{ I } & 0.1 & 2 & 24.60 \\
\hline $2^{\prime}$ & & 0.1 & 4 & 26.82 \\
\hline $3^{\prime}$ & & 0.1 & 6 & 26.14 \\
\hline $1 "$ & \multirow{3}{*}{ II } & 0.1 & 2 & 24.89 \\
\hline 2" & & 0.1 & 4 & 28.82 \\
\hline $3 "$ & & 0.1 & 6 & 26.82 \\
\hline 1"” & \multirow{3}{*}{ III } & 0.1 & 2 & 25.14 \\
\hline 2"' & & 0.1 & 4 & 28.04 \\
\hline 3"' & & 0.1 & 6 & 28.34 \\
\hline $1 ", " '$ & \multirow{3}{*}{ IV } & 0.1 & 2 & 26.14 \\
\hline $2 ", "$ & & 0.1 & 4 & 26.47 \\
\hline 3"'” & & 0.1 & 6 & 27.43 \\
\hline $1, ", '$ & & 0.1 & 2 & 28.04 \\
\hline 2"'”' & & 0.1 & 4 & 28.02 \\
\hline 3"'”' & & 0.1 & 6 & 28.04 \\
\hline
\end{tabular}

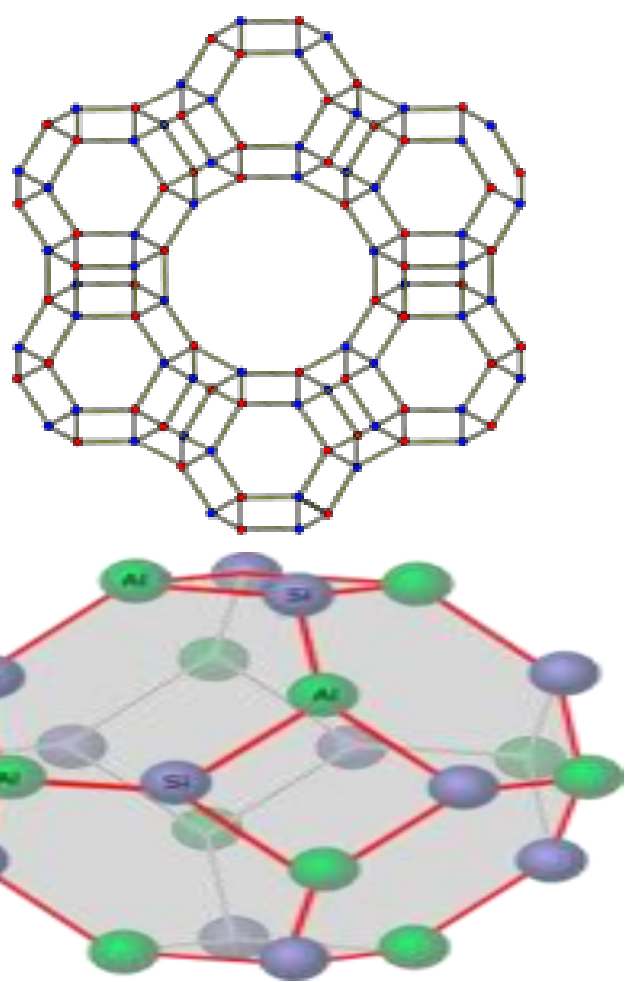

Figure 1 - Structure of the NaY zeolite

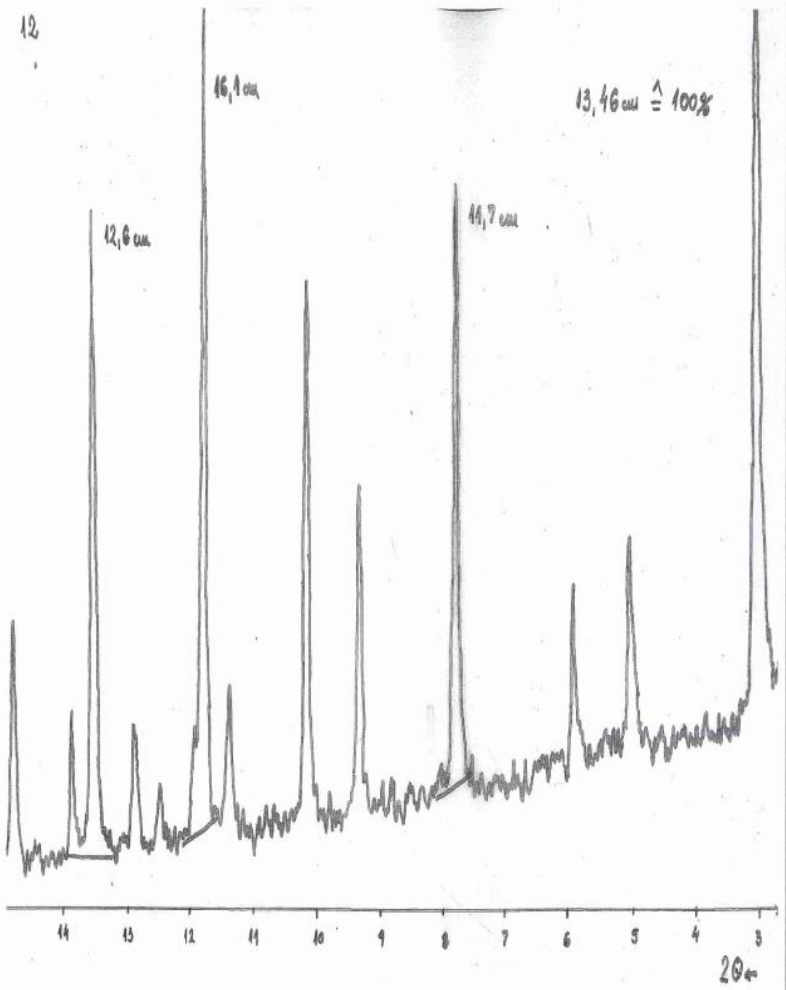

Figure 2 - Difractogram of the NaY zeolite

The diffractogram shows that $\mathrm{NaY}$ zeolite belongs to the fourth group of classification of the zeolites with double six-membered rings (D6R) $[3,4]$. 
Thermal analysis are given in Figure 3 and Figure 4. DTA, DTG and TG curves of the $\mathrm{NaY}$ zeolite are given in Figure 2. Endothermic effect occurs on DTA curve with maximum at $185^{\circ} \mathrm{C}$ as a result of the zeolite's water which is located in the structure of the zeolite. With maximum at $890^{\circ} \mathrm{C}$ exothermic effect occurs when it comes to destroying the structure of the zeolite and turning into a new crystalline phase. TG curve gives the loss of mass and it is $23,60 \%$ (mass). DTG curve gives the dependence of DTA and TG, Figure 4.

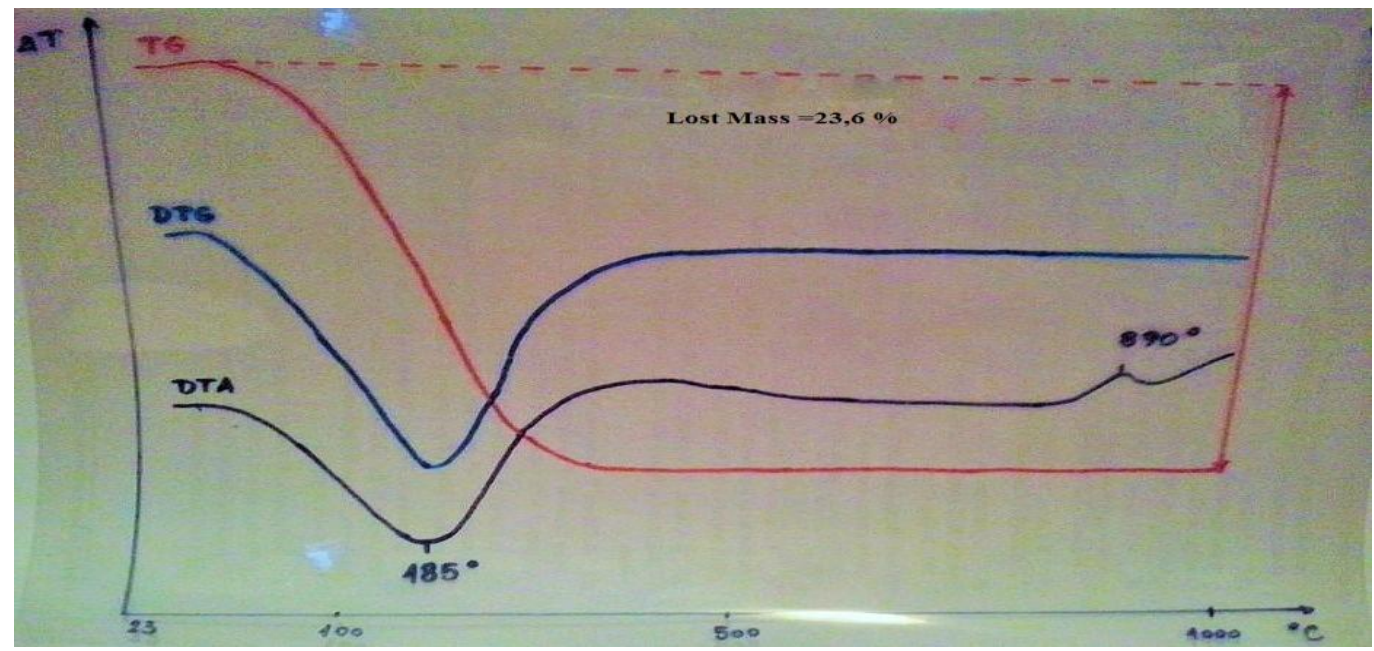

Figure 3 - DTA, DTG i TG of the NaY zeolite

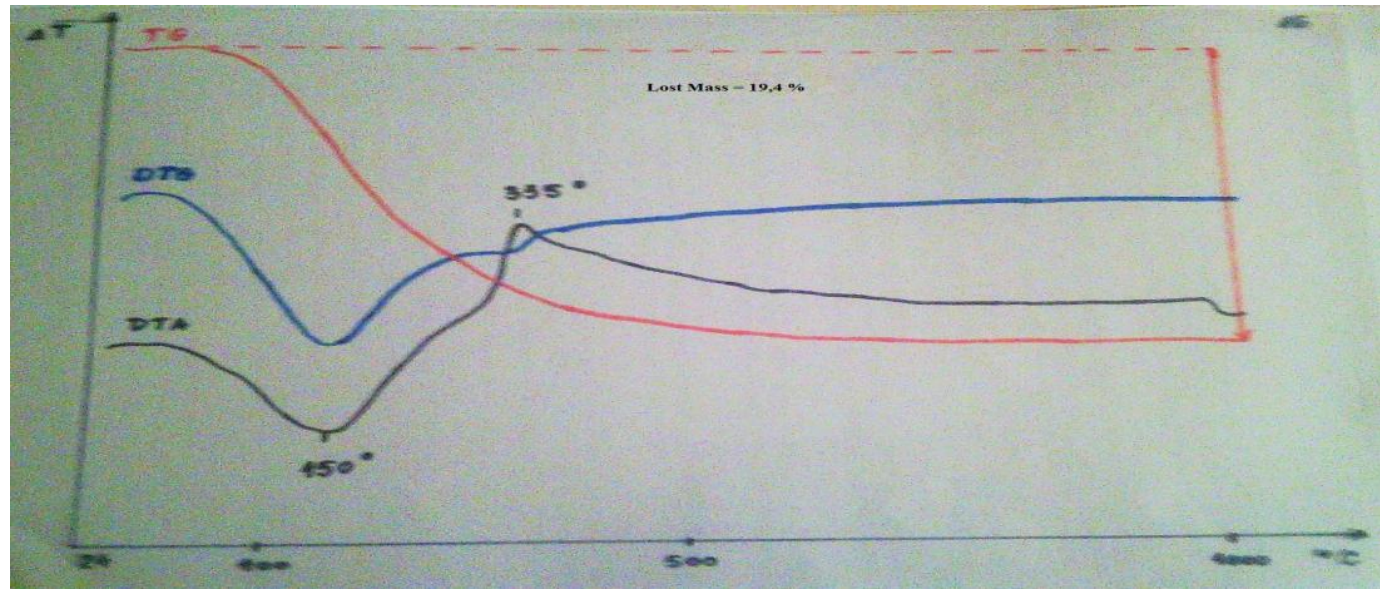

Figure 4 - DTA, DTG i TG of the NaY zeolite + citric acid + surfactants and without surfactants

DTA, DTG and TG curves of the product obtained by extraction of aluminum from the $\mathrm{NaY}$ zeolite with citric acid $\mathrm{c}=0,1 \mathrm{~mol} \cdot \mathrm{dm}^{-3}$ are given in Figure 4. DTA curve is characterized with endothermic and exothermic effects with maximum at $150^{\circ} \mathrm{C}$ and $335^{\circ} \mathrm{C}$, respectively. Exothermic effect results of the presence of organic compositions, in this case citric acid and surfactants. The loss of mass is $19,4 \%$ (mass) determined by DTG curve [3].

\section{CONCLUSION}

The results of our examination indicate that the extraction of aluminum from $\mathrm{NaY}$ zeolite is possible using the citric acid with concentration $c=0,1$ $\mathrm{mol} \cdot \mathrm{dm}^{-3}$. The use of the acid with $\mathrm{c}=0,5 \mathrm{~mol} \cdot \mathrm{dm}^{-3}$ destroys the crystal lattice of the zeolite. Products obtained from our investigations have crystallinity greater than $50 \%$ that accomplished the purpose of our research.

\section{REFERENCES}

[1] Amy H.Roy et al.(1999) Teaching Materials that Matter: An Interactive, Multi-media Module on Zeolites in General Chemistry, The Chemical Educator, 4(3), 243-249.

[2] D.Hoffman, I.Hoffman (1997) Recent applications of zeolites, natural nanostructure materials, J. Toxic. Env. Health, 50, 348-354. 
[3] R.M.Barrer (1982) Hidrothermal Chemistry of Zeolites, FRS Academic Press, London

[4] B.Cekova, V.Zlatanovic, V.Najdenova (1993) Mathematical model of the process of modifization
$\mathrm{NaY}$ Zeolite by the citric acid and tenzides, The $11^{\text {th }}$ International Congress of Chemical Engeneering, Chemical Equipment and Automatization CHISA 93, C5, 104, Praha,Czech Republic.

\section{IZVOD}

\section{MODIFIKACIJA NaY ZEOLITA SA LIMUNSKOM KISELINOM SA PRIMENOM NA TENZIDE}

Zeoliti su popularna grupa minerala za kolekcionare $i$ značajna grupa minerala za industrijske $i$ druge svrhe. Oni kombinuju retkost, lepotu, složenost $i$ jedinstvene kristalne oblike. Tipično, formiraju se u šupljinama ili kesicama od vulkanskih stena. Zeoliti su rezultat veoma niske razrade metamorfizma. Neki oblik zeolita od samo suptilnim količina toplote i pritiska se jedva može nazvati metamorfoznim dok ostali se nalaze u očigledno metamorfnim režimima. Postoje polazna opsežna istraživanja u formiranju zeolita i njihovim jedinstvenim svojstvima.

$\mathrm{NaY}$ zeolit je analog sa prirodnim zeolitom fosfazida i pripada četvrtoj grupi prema klasifikaciji zeolita. Tipičan sastav NaY osnovne ćelije $\mathrm{Na}_{56}\left[\left(\mathrm{AlO}_{2}\right)_{56}\left(\mathrm{SiO}_{2}\right)_{136}\right] \cdot 250 \mathrm{SiO}_{2}$ sadrže dvostruke heksagonalne prstenove (D6R). Ovo istraživanje je fokusirano na NaY zeolite, dobijene hidrotermalnim procesom sa izabranim oksidnim odnosom: $\mathrm{SiO}_{2} / \mathrm{Al}_{2} \mathrm{O}_{3}=9,0 ; \quad \mathrm{Na}_{2} \mathrm{O} / \mathrm{SiO}_{2}=0,33 \mathrm{i}$ $\mathrm{H}_{2} \mathrm{O} / \mathrm{Na}_{2} \mathrm{O}=40$. Hemijski sastav polazne smeše za sintezu određuje hemijsku formulu $2.97 \mathrm{Na}_{2} \mathrm{O}$ - $\mathrm{Al}_{2} \mathrm{O}_{3} \cdot 9 \mathrm{SiO}_{2} \cdot 118.8 \mathrm{H}_{2} \mathrm{O}$. Proces dealuminacije na $\mathrm{NaY}$ zeolitu je izveden primenom limunske kiseline sa koncentracijama 0,1 i 0,5 mol/ $\mathrm{dm}^{3}$ i uvođenjem tenzida (I, II, III, IV). Dealuminatni postupak se izvodi kako bi se izvukla većina sadržaja Al sa zeolitne strukture, čuvajući kristalnu strukturu, uz kristalnost iznad 50\%. NaY zeolit ima solidnu strukturu i zato je potreban proces dealuminacije da bi se modifikovao ovaj materijal u prikladnog katalizatora $i$ za druge namene. Dobijeni proizvodi su analizirani sa X-Ray, DTA, TGA i DTG. Rezultati izvršene dealuminacije su predstavljeni u tabelama. Kritalnost dobijenog zeolita je određena sa $56.90 \%$, u poređenju sa kristalnošću komercijalnog zeolita, koji ima prijavljenu kristalnost od 100\%.

Ključne reči: dealuminacija, limunska kiselina, NaY zeolit, kristalnost.

\section{Naučni rad}

Rad primljen: 22. 01. 2016.

Rad prihvaćen: 16. 03. 2016.

Rad je dostupan na sajtu: www.idk.org.rs/casopis 